\title{
The Effect of Financial Distress, Firm Size, Leverage and Litigation Risk on The Application of Accounting Conservatism In Manufacturing Companies Listed In Indonesia Stock Exchange
}

Ira Septriana ${ }^{1 凶}$, Hermawan Triyono², Agung Prajanto ${ }^{3}$

${ }^{1}$ Accounting Department, Economic and Business Faculty, Dian Nuswantoro University, Indonesia ${ }^{2}$ Accounting Department, Economic and Business Faculty, Dian Nuswantoro University, Indonesia

${ }^{3}$ Accounting Department, Economic and Business Faculty, Dian Nuswantoro University, Indonesia

\section{Article Information}

Article history:

Accepted: April 2021

Approved: July 2021

Published: September 2021

Keywords:

Conservatism Accounting

Financial Distress

Firm Size

Leverage

Litigation Risk

\begin{abstract}
This research aims to analyze the effect of financial distress, firm size, leverage, and litigation risk on implementing the accounting conservatism of manufacturing companies in Indonesia. The population in this research is manufacturing companies listed on the Indonesia Stock Exchanged (IDX) over 2014-2018. Research sample selection used the purposive sampling method. Obtained company data that meet the research criteria as many as 169 companies, so that the total research data is 149 data. The analysis methods in this research are multiple regression analysis. Based on the test results of the research conclude that variables of the board of financial distress, firm size, and litigation risk have no effect on accounting conservatism implemented of manufacturing companies. Meanwhile, the variable of leverage affects the accounting conservatism's implemented by manufacturing companies.
\end{abstract}

How to Cite: Septriana, I., Triyono, H., \& Prajanto, A. (2021). The Effect of Financial Distress, Firm Size, Leverage and Litigation Risk on The Application of Accounting Conservatism In Manufacturing Companies Listed In Indonesia Stock Exchange. Jurnal Penelitian Ekonomi dan Bisnis, 6(2), 100 106. doi:https://doi.org/10.33633/jpeb.v6i2.4303

$\begin{array}{lr}\square_{\text {correspondence address: }} & \text { ISSN } \\ \text { Fakultas Ekonomi dan Bisnis, Universitas Dian Nuswantoro, } & 2442-5028 \text { (print) 2460-4291 } \\ \text { Jalan Nakula 1 nomor 5-11, Pendrikan Kidul, Semarang } & \text { (online) } \\ \text { E-mail: ira.septriana@dsn.dinus.ac.id } & \text { DOI: 10.33633/jpeb.v6i2.4303 }\end{array}$

Jalan Nakula 1 nomor 5-11, Pendrikan Kidul, Semarang DOI: 10.33633/jpeb.v6i2.4303 
Ira Septriana, Hermawan Triyono, and Agung Prajanto: The Effect of Financial Distress, Firm Size, Leverage and Litigation Risk on The Application of Accounting Conservatism In Manufacturing Companies Listed In Indonesia Stock Exchange

\section{INTRODUCTION}

IFRS (International Financial Reporting Standards) is an International Accounting Standard used by companies in the world on an international scale. IASB (International Accounting Standards Board) is an international body that deals with developments and accounting standards and issues the IFRS. Indonesia, as one of the G-20 members, must follow the agreement to carry out IFRS Convergence. IFRS convergence itself aims to improvise on corporate financial information's quality, especially companies listed on the Stock Exchange.

Based on PSAK 68, the Financial Statements use valuations based on Fair Value. Using Fair Value in valuation here means that if there is no active market value, it must conduct self-assessment (competence required) or use the services of an appraiser. This results in a managers' expectation in the face of uncertainty are to apply conservative accounting principles. Accounting conservatism recognizes a decrease in assets even though the event has not yet been realized, but if there is an increase in unrealized assets, it cannot be identified.

Financial statements become the primary means because it provides information to assess the economic condition of the company and show company management's ability to manage the company's wealth. Users will use the News in the financial statement disclosures to decide.

Deviyanti (2012) suggests accounting standards in which goals, rules, and accounting principles form the basis of good financial reports. Thus, users are accountable for their content and value. Generally accepted accounting principles in the financial statements will allow management to select accounting rules and estimates. This flexibility affects managers' decisions when deciding to have accounting records and reporting on company transactions (Wardhani, 2008).

In choosing an accounting method, company management is careful in making financial reports because the company must decide the proper way for economic conditions and can cause instability in the company's economic conditions (Iskandar, 2016). Company management may also choose to report optimistic or conservative financial reports.

Ardina \& Januarti (2012) stated that an optimistic financial report is an exaggerated financial report that can lead to and even harm users of financial statements. Unlike the case with optimistic financial reports, conservative financial reports are more cautious and pessimistic because the company's economic activity will experience uncertainty in the future. The measurement, recognition, and calculation are conservative.

According to Hapsari (2012), financial distress is a condition in which the company's operating cash flow is not enough to pay off current liabilities (such as trade payable or interest expenses), and the company must make repairs. Conservatism has a basic principle: (1) it must admit that losses are very likely to occur but must not expect profits before they occur. (2) if faced with several choices, the accountant must choose the accounting method that is least preferred (Suharli, 2009). Accounting conservatism is reducing net assets or reducing earnings in response to bad news and not increasing profits in response to good News Basu (1997). Platt \& Marjorie (2002)stated that the usefulness of information on financial distress that occurs in the company is (1) Able to direct management steps to prevent problems before bankruptcy occurs. (2) Management can carry out mergers to pay debts and manage the company properly. (3) Providing early warning about bankruptcy that will occur at a later date.

The official definition of accounting conservatism in the Glossary of Concept Statement No. 2 The Financial Accounting Statement Board (FASB) defines conservatism as a prudent reaction in the uncertainties inherent in the company to try to make sure that uncertainties and risks in the business environment are sufficiently considered. The principle of conservatism is still a subject of debate for researchers, giving rise to pros and cons. Researchers who support accounting conservatism argue that when applied in preparing financial statements, the conservatism principle can avoid managers' desire to manipulate earnings (Fala, 2007). In this research, the writer wants to know and test what aspects can influence applying accounting conservatism. This study adds a litigation risk variable different from previous studies, intending to find out what can affect the application of conservatism accounting.

\section{METHOD}

\section{Types of Research and Population Research Overview}

This type of research is quantitative research, namely research that aims to test the hypothesis, 
the data used is measured and produces conclusions that can prove the hypothesis. According to Sugiyono (2013), the population is a levelling area that includes quality subjects and objects determined by the researcher to understand and draw conclusions. The population used in this study are all manufacturing companies listed on the Indonesia Stock Exchange (BEI) for the 2014-2018 period.

\section{Sampling Method}

Sampling in this study using the purposive sampling method, namely determining the sample with certain criteria, is not random. The sample choice in this study used the following criteria:

1. Manufacturing companies listed on the IDX and reporting financial statements for the 20142018 period.

2. There is complete data for the 2014-2018 period.

3. Companies that have a negative CONTACT value.

\section{Method of Collecting Data}

The data used in this study uses the methods provided by the company. The data used in this study is secondary data in the form of financial statements of manufacturing companies listed on the Stock Exchange 2014-2018.

\section{Operational Definition and Variable Measurement Accounting Conservatism}

Accounting conservatism means being careful as soon as possible to record liabilities and expenses even though the results are uncertain and record assets and income when they are received. Accounting conservatism in this study uses an accrual model (Givoly \& Hayn, 2000). If the company applies accounting conservatism, the value will be even more negative. The formula for accounting conservatism is as follows:

$$
\text { ConAcc }=\frac{((\text { Net profit }+ \text { Depreciation })-\text { Operating Cash Flow }) x-1}{\text { Total Assets }}
$$

\section{Financial Distress}

Financial distress is a situation when a company cannot pay off its obligations. Measurement of financial distress in this study using Altman (Z-Score). The formula is as follows :

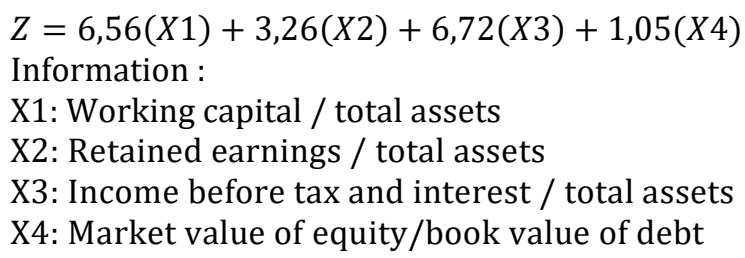

\section{Firm Size}

Company size shows the size of the company as seen through total assets, total sales, and others. Measurement of company size using total assets because the company is large or small can be known. If the number of assets is large, it is a large company or vice versa if the total assets are small, the company is a small company. Company size, according to Hartono (2015), uses the formula:

Size $=\log$ Total Assets

\section{Leverage}

Leverage is a source of funds that comes from external parties. Leverage shows how much debt pays for the company's assets. Leverage is calculated using the Debt to Asset Ratio (DAR), accompanied by the formula:

Leverage $=\frac{\text { Totaldebt }}{\text { Totalassets }}$ 


\section{Litigation Risk}

DER measures the litigation risk arising from creditors.

$$
D E R=\frac{\text { Total Amoun of debt }}{\text { Total equity }}
$$

\section{RESULT AND DISCUSSION}

\section{Descriptive Statistical Analysis}

The following results of descriptive statistical analysis of the study can be seen below:

Table 1 Descriptive Statistics Analysis Results

\begin{tabular}{lcrrrr}
\hline & $\mathrm{N}$ & \multicolumn{1}{c}{ Minimum } & \multicolumn{1}{c}{ Maximum } & \multicolumn{1}{c}{ Mean } & \multicolumn{1}{c}{ Std. Deviation } \\
\hline Acc Conservatism & 169 & -.7880 & -.0011 & -.057737 & .0826453 \\
Financial Distress & 169 & -7.3316 & 24585.4383 & 182.260530 & 1905.9484439 \\
Firm Size & 169 & .0000 & 14.4708 & 12.226705 & 1.1896334 \\
Leverage & 169 & .0004 & 2.0558 & .421368 & .2593392 \\
Litigation Risk & 169 & -8.3383 & 94.0997 & 1.492772 & 7.3222493 \\
\hline Valid N (listwise) & 169 & & & &
\end{tabular}

\section{Multiple Linear Regression Model}

This multiple analysis test aims to see whether Financial Distress, Firm Size, Leverage, and Litigation Risk affect accounting conservatism. Table 2 is the Results of the Multiple Linear Regression Model.

Table 2. Multiple Linear Regression Test Results

\begin{tabular}{lrc}
\multicolumn{1}{c}{ Model } & \multicolumn{2}{c}{ Unstandardized Coefficients } \\
\cline { 2 - 3 } & \multicolumn{1}{c}{$\mathrm{B}$} & Std. Error \\
\hline (Constant) & -.015 & .028 \\
Financial Distress & $6.503 \mathrm{E}-007$ & .000 \\
Firm Size & $-9.672 \mathrm{E}-005$ & .002 \\
Leverage & .071 & .013 \\
Litigation Risk & .000 & .000 \\
\hline \multicolumn{1}{c}{ Dependent Variable: ACC CONSERVATISME }
\end{tabular}

From table 2, so that it can be arranged multiple linear regression equations, among others: $Y=-0,015+0,0000006503 \mathrm{X} 1-0,00009672 \mathrm{X} 2-0,071 \mathrm{X} 3-0,000 \mathrm{X} 4+\mathrm{e}$

\section{Model test}

The coefficient of determination test is used to see the effect of all independent variables used on accounting conservatism. Table 3 is the result of the determination coefficient test.

Table 3. Coefficient of Determination

\section{Model Summary}

\begin{tabular}{crrrr}
\hline Model & R & R square & Adjusted R Square & $\begin{array}{c}\text { Std. The error of the } \\
\text { Estimate }\end{array}$ \\
\hline 1 & $.432 \mathrm{a}$ & .187 & .187 & .0336690 \\
\hline
\end{tabular}


Table 4 is the Result of the F Statistical Test.

Table 4. Test Results F

\begin{tabular}{|c|c|c|c|c|c|c|}
\hline \multicolumn{7}{|c|}{ ANOVA $^{a}$} \\
\hline & Model & Sum of Squares & $\mathrm{df}$ & Mean Square & $\mathrm{F}$ & Sig. \\
\hline \multirow{3}{*}{1} & Regression & .037 & 4 & .009 & 8.212 & $.000 \mathrm{~b}$ \\
\hline & Residual & .162 & 143 & .001 & & \\
\hline & Total & .199 & 147 & & & \\
\hline
\end{tabular}

The $F$ test value of 8,212 with a significance of 0,000 is the result of the significance test. There is a significant relationship between the dependent variable Accounting Conservatism with the overall independent variables of Financial Distress, Company Size, Leverage, and Litigation Risk of a significance value $<0.05$.

\section{Hypothesis test}

This test aims to see the partial or the effect of each independent variable on the dependent variable. The t-test considers the significance value obtained by each variable. Table 5 is the result of the $t$ statistical test.

Table 5. Test Results t

\begin{tabular}{ll}
\multicolumn{1}{c}{ Coefficients } \\
\hline \multicolumn{1}{c}{ Model } & Sig. \\
& \\
\hline (Constant) & .587 \\
Financial Distress & .641 \\
Firm Size & .966 \\
Leverage & .000 \\
Litigation Risk & .641 \\
\hline
\end{tabular}

The result of the $t \mathrm{t}$-test calculation means that the Financial Distress has a significance value of $0.641>$ from the significance level of 0.05. Suppose Financial Difficulty does not affect Accounting Conservatism. $\mathrm{T}$ the hypothesis $\mathrm{H}$, one which states that Financial Distress affects conservatism, is rejected.

Firm size has a significance value of $0.966>$ from the 0.05 significance level. So that shows if the size of the company does not affect accounting conservatism. Thus, the H2 hypothesis, which states the size of the company influences accounting conservatism, is rejected.

Leverage has a significance value of $0,000<$ from the significance level of 0.05 . This shows that Leverage affects Accounting Conservatism. Thus, the H3 hypothesis, which states that Leverage influences Accounting Conservatism, is accepted.

Litigation risk has a significance value of $0.641>$ from the significance level of 0.05 . So it shows if Litigation Risk does not affect Accounting Conservatism. Thus, the H4 hypothesis, which states that Litigation Risk influences Accounting Conservatism, is rejected.

\section{The Effect of Financial Distress on the Application of Accounting Conservatism}

Based on the research and analysis that has been done, the variable Financial Distress does not affect Accounting Conservatism. Thet-test results obtained a significance value of $0.690>$ of a significance level of 0.05. This shows if Financial Distress does not affect Accounting Conservatism, which means that $\mathrm{H} 1$ is rejected.

The results of this study are not by the positive accounting theory in the bonus plan. Managers tend to increase profits and do not apply the principle of conservatism to increase bonuses that they can. However, the results of testing in this study indicate that Financial Distress does not affect the 
Ira Septriana, Hermawan Triyono, and Agung Prajanto: The Effect of Financial Distress, Firm Size, Leverage and Litigation Risk on The Application of Accounting Conservatism In Manufacturing Companies Listed In Indonesia Stock Exchange

application of Accounting Conservatism due to conservative financial statements that will prevent companies from exaggerating profits and limiting dividend distribution, thereby indirectly increasing the availability of cash to pay debts and reducing the likelihood the occurrence of Financial Distress.

The results of this study support previous research by Ningsih (2011), which proves that Financial Distress does not affect Accounting Conservatism. However, the results of this observation are not in line with observations of Noviantari \& Ratndi (2015) which prove that Financial Distress influences Accounting Conservatism.

\section{Effect of Firm Size on the application of Accounting Conservatism}

Based on the research and analysis that has been done, the variable Firm Size does not affect Accounting Conservatism. The t-test results obtained a significance value of $0.838>$ from the significance level of 0.05 . This shows that the company's size has no effect on accounting conservatism, which means that $\mathrm{H} 2$ is rejected.

The results of this study are not in accordance with the positive accounting theory on the political cost hypothesis, is namely that companies tend to reduce profits to reduce the tax burden, which means the company will apply the principle of accounting conservatism. However, the results of testing in this study indicate that firm size does not affect the application of accounting conservatism because the company will prefer to display high profits to attract investors and creditors' attention and gain public trust rather than applying the principle of accounting conservatism to reduce the tax burden.

The results of this observation are in accordance with previous observations by Utama \& Titik (2018), which prove that Firm Size does not affect Accounting Conservatism. However, the results of these observations are not in accordance with observations of Noviantari \& Ratnadi (2015) and Sulastri, Mulyati, \& Icih (2018), which prove that firm size influences accounting conservatism.

\section{Effect of Leverage on the application of Accounting Conservatism}

From the results of research and analysis that have been done, the Leverage variable influences Accounting Conservatism. The t-test results obtained a significance value of $0,000<$ from the significance level of 0.05 . This shows if leverage affects Accounting Conservatism, which means that H3 is accepted.

The results of this study are in accordance with the positive accounting theory on the debt agreement hypothesis, namely that companies that will tend to reduce the debt ratio by increasing the reported earnings of the current period tend not to be conservative.

This observation is in accordance with observations that have been carried out by Noviantari \& Ratnadi (2015) and Utama \& Titik (2018), which prove that Leverage influences Accounting Conservatism. However, the results of this study are not in line with research results from Rohminatin (2016), which proves that leverage does not affect Accounting Conservatism.

\section{The Effect of Litigation Risk on the Application of Accounting Conservatism}

From the research and analysis that have been done, the Litigation Risk variable does not affect Accounting Conservatism. The t-test results obtained a significance value of $0.641>$ of a significance level of 0.05 . This shows if Litigation Risk does not affect Accounting Conservatism, which means that $\mathrm{H} 4$ is rejected.

\section{CONCLUSIONS AND RECOMMENDATION}

Based on research that has been worked on samples obtained as many as 149 Manufacturing Companies listed on the Stock Exchange in 2014-2018. From this study, there are limitations that the Adjusted value (R2) obtained from this research model is still very weak that is equal to 0.178 or equivalent to $17.8 \%$, and the remaining $82.2 \%$ is explained by other variables outside the study.

According to the limitations in this study, there are still many shortcomings, so it is hoped that future studies will pay more attention to the following matters:

1. For further research, it is recommended to add other variables that can influence Accounting Conservatism, for example, Managerial Ownership Structure, Profitability, and Cash Flow.

2. For investors, it is recommended to analyze the financial statements related to steps to provide capital for the company by considering financial distress, firm size, leverage, and litigation risk. 
3. For companies, it is recommended to identify the symptoms of a company going bankrupt and anticipate it from happening.

\section{REFERENCES}

Ardina, A. M. Y., \& Januarti, I. (2012). Penggunaan Perspektif Positive Accounting Theory Terhadap Konservatisme Akuntansi di Indonesia. Diponegoro Jornal of Accounting, 1(1), 1-15.

Basu, S. (1997). The Conservatism Principle and The Asymmetric Timeliness of Earnings. Journal of Accounting and Economic, 24(1), 1-51.

Deviyanti, D. A. (2012). Faktor-faktor yang Mempengaruhi Penerapan Konservatisme dalam Akuntansi. Universitas Diponegoro.

Fala, D. Y. A. (2007). Pengaruh Konservatisme Akuntansi Terhadap Penilaian Ekuitas Perusahaan Dimoderasi oleh Good Corporate Governance. Makasar: Makalah Simposium Nasional Akuntansi $\mathrm{X}$.

Givoly, D., \& Hayn, C. (2000). The Changing Timeliness-Series Properties of Earnings, Cash Flow and Accrual: Has Financial Accounting Become More Conservative? Journal Accounting and Economics, (29 Juni), 287-320.

Hapsari, E. I. (2012). Kekuatan Rasio Keuangan dalam Memprediksi Financial Distress Perusahaan Manufaktur yang Terdaftar di BEI. Jurnal Dinamika Akuntansi.

Hartono, J. (2015). Teori Portofolio dan Analisis Investasi (Edisi Kese). Yogyakarta: BPFE.

Iskandar, O. R. (2016). Pengaruh Debt Covenant, Bonus Plan, dan Political Cost Terhadap Konservatisme Akuntansi (Studi Empiris pada Perusahaan Manufaktur Subsektor Industri Barang Konsumsi yang Terdaftar di BEI Tahun 2012-2015). STIE Indonesia Banking School.

Ningsih, E. (2011). Pengaruh Tingkat Kesulitan Keuangan Perusahaan dan Risiko Litigasi Terhadap Konservatisme Akuntansi (Studi Empiris pada Perusahaan Manufaktur yang Terdaftar di BEI).

Noviantari, N. W., \& Ratnadi, N. M. D. (2015). Pengaruh Financial Distress, Ukuran Perusahaan, dan Leverage pada Konservatisme Akuntansi. E-Jurnal Akuntansi Universitas Udayana, 11(3), 646660.

Platt, H., \& Marjorie. (2002). Predicting Corporate Financial Distress. Journal of Financial Service Proffesionals.

Rohminatin. (2016). Faktor-faktor yang Mempengaruhi Penerapan Konservatisme Akuntansi (Studi pada Perusahaan Manufaktur yang Terdaftar di BEI. Jurnal Ilmiah Infotek, 1(1).

Sugiyono. (2013). Metode Penelitian Pendidikan Pendekatan Kuantitatif, Kualitatifdan R\&D. Bandung: Alfabeta.

Suharli, M. (2009). Akuntansi dan Pelaporan Keuangan untuk Perusahaan Jasa. Retrieved from http://bisindo.com

Sulastri, A., Mulyati, S., \& Icih. (2018). Analisa Pengaruh ASEAN Corporate Governance Scorecard, Leverage, Size, Growth Opportunities dan Earnings Pressure Terhadap Konservatisme Akuntansi (Studi Kasus pada Perusahaan Top Rank 50 ASEAN Corporate Governance Scorecard di Indonesia yang Terdaftar di. Accounting Research Journal of Suttatmadja, 1(1).

Utama, E. P., \& Titik, D. F. (2018). Pengaruh Leverage, Ukuran Perusahaan, Kepemilikan Manajerial Dan Profitabilitas Terhadap Konservatisme Akuntansi. E-Proceeding of Management, 5(1), 720.

Wardhani, R. (2008). Tingkat Konservatisme Akuntansi di Indonesia dan Hubungannya dengan Karakteristik Dewan sebagai Salah Satu Mekanisme Corporate Governance. Universitas Indonesia. 